\title{
Gambaran kadar lipid trigliserida pada pasien usia produktif di Puskesmas Bahu Kecamatan Malalayang Kota Manado periode November 2014 - Desember 2014
}

\author{
${ }^{1}$ Anggara E. Watuseke \\ ${ }^{2}$ Hedison Polii \\ ${ }^{3}$ Pemsi M. Wowor
}

\author{
${ }^{1}$ Kandidat Skripsi Fakultas Kedokteran Universitas Sam Ratulangi Manado \\ ${ }^{2}$ Bagian Fisiologi Fakultas Kedokteran Universitas Sam Ratulangi Manado \\ ${ }^{3}$ Bagian Farmakologi Klinik dan Terapi Fakultas Kedokteran \\ Universitas Sam Ratulangi Manado \\ Email: anggawatuseke@gmail.com
}

\begin{abstract}
Trigliserida is especial fat in human being food and represent especial deposit fat at animal and plant. Increase of trigliserida earn because of body overweight, also physical activities, age, disparity of genetic, or high diet of carbohydrate. Purpose To know picture of trigliserida at productive age pursuant to age at Puskesmas Bahu Kecamatan Malalayang, Manado. Method The design's study is a descriptive study with cross sectional method. Result Responder owning rate of trigliserida highest reside in spanning age 31-40 years old equal $46,15 \%$, second sequence at spanning age $51-60$ years old equal $36,36 \%$, third sequence at spanning age $41-50$ years old equal $20 \%$. Pursuant to gender, responder owning rate of trigliserida highest is men equal to $36,85 \%$ and women equal to $16,13 \%$. Pursuant of job responder owning rate of trigliserida highest is private sector $35,72 \%$, PNS equal to $23,81 \%$, and third sequence is unemployment equal $20 \%$. Conclusion: The highest level of trigliserida is from 31-40 years old, male, and who has private jobs. This proves that triglyceride levels can be effected by age, sex, and occupation.
\end{abstract}

Keywords: lipid triglycerides, the productive age.

\begin{abstract}
Abstrak: Trigliserida adalah lemak utama dalam makanan manusia dan merupakan lemak simpanan utama pada tumbuhan dan hewan. Peningkatan trigliserida dapat disebabkan oleh kelebihan berat badan, karna juga aktivitas fisik, usia, kelainan genetik, atau diet tinggi karbohidrat. Tujuan penelitian Untuk mengetahui gambaran trigliserida pada usia produktif berdasarkan usia di Puskesmas Bahu, Kecamatan Malalayang, Kota Manado. Desain penelitian Penelitian ini bersifat deskriptif dengan menggunakan metode potong lintang. Hasil penelitian responden yang memiliki kadar trigliserida tertinggi berada pada rentan usia 31 - 40 tahun sebesar $46,15 \%$, urutan kedua pada rentan usia $51-60$ tahun sebesar 36,36\%, urutan ketiga pada rentan usia 41 - 50 tahun sebesar 20\%. Berdasarkan jenis kelamin, responden yang memiliki kadar trigliserida tinggi terbanyak adalah laki - laki sebesar $36,85 \%$ dan perempuan sebesar $16,13 \%$. Berdasarkan jenis pekerjaan responden yang memiliki kadar trigliserida tinggi terbanyak adalah swasta sebesar 35,72\%, urutan kedua PNS sebesar 23,81\%, dan urutan ketiga tak bekerja sebesar 20\%. Simpulan: Kadar trigliserida tertinggi ada pada rentan usia 31 - 40 tahun, jenis kelamin laki - laki dan pekerjaan swasta. Hal ini membuktikan bahwa ada hubungan antara usia, jenis kelamin dan pekerjaan dengan peningkatan kadar trigliserida.
\end{abstract}

Kata kunci: lipid trigliserida, usia produktif. 
Watuseke, Polii, Wowor: Gambaran kadar lipid...

Trigliserida merupakan penyimpanan lipid yang utama didalam jaringan adipose, bentuk lipid ini akan terlepas setelah terjadi hidrolisis oleh enzim lipase yang sensitif hormon menjadi asam lemak bebas dan gliserol. Asam lemak bebas akan terait pada albumin serum dan untuk pengangkutannya ke jaringan, tempat asam lemak tersebut dipakai sebagai sumber bahan bakar yang penting. ${ }^{1}$ Usia produktif adalah usia dimana seseorang mampu melakukan tindakan kreatif yang dapat menghasilkan sesuatu. Tindakan produktif dapat berupa tindakan kerja keras, tindakan kerja cerdas, mampu bersikap mandiri, serta memiliki pandangan hidup dan wawasan ke depan. Rentang usia produktif menurut BKKBN adalah antara 15 - 59 tahun. Pada umumnya, dengan gaya hidup normal, trigliserida tidak meningkat saat usia produktif. $^{2}$ Dislipidemia digambarkan sebagai suatu keadaan yang ditandai dengan peningkatan trigliserida dan penurunan kolesterol High Density Lipoprotein (HDL), kolesterol Low Density Lipoprotein (LDL) biasanya normal namun mengalami perubahan struktur berupa peningkatan small dense LDL. Dislipidemia memiliki prevalensi yang tinggi hampir di seluruh negara di dunia, diantaranya Cina, tepatnya kota Beijing. Suatu penelitian yang dilakukan pada 3251 orang dewasa dengan umur antara 45-89 tahun, didapatkan prevalensi dislipidemia sebesar $56.1 \pm 0.9 \%$. Nilai ratarata konsentrasi kolesterol total, kolesterol HDL, kolesterol LDL, dan trigliseridemia yakni $4.92 \pm 1.01 \mathrm{mmol} / \mathrm{L}, \quad 1.61 \pm 0.36$ $\mathrm{mmol} / \mathrm{L}, 2.88 \pm 8.85 \mathrm{mmol} / \mathrm{L}$, dan $1.76 \pm 1.26$ $\mathrm{mmol} / \mathrm{L} .^{4,5}$ Belum banyak penelitianpenelitian yang belum dilakukan di Indonesia. Oleh karena itu, melalui penelitian ini peneliti berharap hasil yang didapatkan dapat membantu menambah informasi tentang gambaran lipid trigliserida dan hubungannya dengan usia produktif sekaligus menjadi pelengkap data tentang pola trigliserida di Puskesmas Bahu, Kecamatan Malalayang.

Berdasarkan uraian teori di atas, maka peneliti tertarik ingin mengetahui tentang
Gambaran kadar lipid trigliserida pada Usia produktif.

\section{METODE PENELITIAN}

Penelitian ini bersifat deskriptif dengan menggunakan metode potong lintang (crossectional) dan Penelitian ini dilakukan di Puskesmas Bahu Kecamatan Malalayang Kota Manado, Waktu penalaksanaan penelitian ini akan dilaksanakan selama 2 bulan, yaitu pada bulan November sampai bulan Desember 2014. Populasi Seluruh pasien usia produktif usia 15-64 tahun di Puskesmas Bahu Kecamatan Malalayang Kota Manado sebanyak 50 pasien. Pengambilan sampel menggunakan teknik purpossive sampling sebanyak 50 pasien. Variable penilitian ini yang di ambil Kadar lipid trigliserida dan usia produktif.

Alat dan bahan yang di gunakan semprit untuk pengambilan darah, sarung tangan, kapas dan alkohol, tabung EDTA, tourniquet, dan lipid pro. Cara kerja penelitian ini yaitu :

1. Menjelaskan pada subjek tentang proses pemngambilan darah.

2. Tentukan vena untuk pengambilan darah.

3. Ikat lengan dengan tourniquet $7-10 \mathrm{~cm}$ dari lipatan siku

4. Lakukan disinfeksi dengan menggunakan kapas dan alkohol

5. Tusukan jarum dengan sudut 30-45 derajat, lepaskan tourniquet

6. Setelah mendapatkan darah yang cukup, tarik jarum secara perlahan - lahan dan tekan bagian yang ditusuk dengan menggunakan kapas

7. Lepaskan jarum dari semprit dan masukan ke dalam tabung EDTA

8. Setelah itu sampel di bawa ke laboratorium umtuk dilakukan pemeriksaan kadar trigliserida dalam darah.

\section{HASIL PENELITIAN}

Berdasarkan data penelitian yang masih kurang mengenai gambaran lipid trigliserida pada peningkatan usia produktif, maka peneliti menjabarkan hasil penelitian sebagai berikut. 
Tabel 1. Gambaran Umur Responden

\begin{tabular}{ccc}
\hline Umur & Tg. Tinggi & $(\%)$ \\
\hline $21-30$ & 0 & $0 \%$ \\
\hline $31-40$ & 6 & $46,15 \%$ \\
\hline $41-50$ & 3 & $20 \%$ \\
\hline $51-60$ & 4 & $36,36 \%$ \\
\hline $61-64$ & 0 & $0 \%$ \\
\hline Total & 13 & $26 \%$ \\
\hline
\end{tabular}

Berdasarkan Tabel 1 hasil penelitian menunjukkan umur responden dengan trigliserida tertinggi adalah $31-40$ tahun $(46,15 \%)$.

Tabel 2. Gambaran Jenis Kelamin Responden

\begin{tabular}{ccc}
\hline Jenis kelamin & Tg. Tinggi & $(\%)$ \\
\hline Laki - laki & 7 & $36,85 \%$ \\
\hline Perempuan & 5 & $16,13 \%$ \\
\hline Total & 12 & $24 \%$ \\
\hline
\end{tabular}

Berdasarkan Tabel 2 hasil penelitian menunjukan jenis kelamin responden dengan trigliserida tertinggi adalah laki laki (36,84\%).

Tabel 3. Gambaran Pekerjaan Responden

\begin{tabular}{ccc}
\hline Pekerjaan & Tg. tinggi & $(\%)$ \\
\hline PNS & 5 & $23,81 \%$ \\
\hline Swasta & 5 & $35,72 \%$ \\
\hline Tak Bekerja & 3 & $20 \%$ \\
\hline Total & 13 & $27 \%$ \\
\hline
\end{tabular}

Berdasarkan Tabel 3 hasil penelitian menunjukan pekerjaan responden dengan trigliserida tertinggi adalah swasta $(35,72 \%)$.

Tabel 4. Gambaran Kadar Trigliserida Responden

\begin{tabular}{ccc}
\hline Responden & Jumlah & $(\%)$ \\
\hline Normal & 38 & $76 \%$ \\
\hline $\begin{array}{c}\text { Tidak } \\
\text { normal }\end{array}$ & 12 & $24 \%$ \\
\hline Total & 50 & $100 \%$ \\
\hline
\end{tabular}

Berdasarkan Tabel 4 hasil penelitian menunjukan jumlah responden dengan trigliserida tertinggi berjumlah 12 (24\%) responden.

\section{BAHASAN}

Penelitian ini dilakukan kepada responden usia produktif di Puskesmas Bahu Kecamatan Malalayang. Berdasarkan hasil penelitian yang dilakukan pada 50 responden yang merupakan pasien Puskesmas Bahu menunjukkan kadar lipid trigliserida normal berjumlah 12 responden laki-laki (persentase sebesar 63,158\% dari total responden laki-laki) dan 26 responden perempuan (persentase sebesar 83,871\% dari total responden perempuan) total 38 responden sedangkan yang tidak normal berjumlah 7 responden laki-laki (persentase sebesar $36,842 \%$ dari total responden lakilaki) dan 5 responden perempuan (persentase sebesar 16,129\% dari total responden perempuan) total 12 responden.

Pada wanita, trigliserida umumnya lebih rendah dibandingkan dengan pria. Tetapi pada waktu menopause, trigliserida wanita cenderung meningkat dan mengakibatkan insiden terjadinya penyakit koroner pada wanita meningkat juga. Konsumsi alkohol, asam lemak jenuh, karbohidrat, dan jumlah kalori yang tinggi dapat meningkatkan trigliserida. ${ }^{5}$

Obesitas dan diabetes yang tidak dikendalikan menjadi penyebab paling umum terjadinya kadar trigliserida yang tinggi. Kadar trigliserida tinggi terjadi ketika seseorang banyak mengonsumsi makanan yang mengandung karbohidrat atau kadar gula yang tinggi. Risiko terkena penyakit jantung akan meningkat seiring dengan tingginya kadar trigliserida seseorang. ${ }^{6}$

Ada kemungkinan, tingginya kadar trigliserida pada beberapa responden disebabkan oleh obesitas dan diabetes. Namun, peneliti tidak mengukur IMT dan kadar gula darah responden. Hal ini disebabkan oleh keterbatasan jenis pemeriksaan yang diberikan kepada responden yang hanya mengukur kadar trigliserida saja. 
Berdasarkan hasil dari tabel 2 didapatkan kadar trigliserida tinggi terbanyak berada pada rentang usia $31-40$ tahun sebanyak 6 responden. Sedangkan kadar trigliserida normal terbanyak berada pada rentang usia 41 - 50 tahun sebanyak 12 responden.

Berdasarkan hasil dari tabel 3 didapatkan kadar trigliserida normal berjumlah 12 responden laki-laki dan 26 responden perempuan (total 38 responden) sedangkan yang tidak normal berjumlah 7 responden laki-laki dan 5 responden perempuan (total 12 responden).

Berdasarkan hasil dari tabel 4 didapatkan kadar trigliserida berdasarkan jenis pekerjaan. Kadar trigliserida normal terbanyak pada jenis pekerjaan sebagai Pegawai Negeri Sipil dengan 16 responden sedangkan kadar trigliserida tinggi terbanyak responden yang tak bekerja sebanyak 3 orang.

Kadar trigliserida dipengaruhi oleh beberapa faktor, yaitu usia, jenis kelamin dan aktivitas fisik. Pada sebuah penelitian di Dinas Kesehatan Sulawesi Selatan, tingkat aktivitas fisik pekerja kantoran termasuk dalam kategori sedang dan rendah. Selain itu pekerja kantoran yang memiliki status gizi lebih mempunyai pola makan yang kurang baik dan aktivitas fisik yang rendah. Aktivitas fisik yang kurang dan pola makan yang salah berisiko mengalami penumpukan lemak serta trigliserida dalam tubuh. Kadar trigliserida dalam darah juga dipengaruhi oleh asupan. Asupan lemak dan karbohidrat yang berlebihan dapat meningkatkan kadar trigliserida dalam darah. Trigliserida yang tinggi dapat diatasi dengan cara mengatur asupan. Konsumsi sayur dan buah yang tinggi akan serat serta vitamin dapat menurunkan kadar trigliserida dalam darah. $^{7}$

\section{SIMPULAN}

Berdasarkan usia, kadar trigliserida tertinggi berada pada rentang usia 31-40 tahun dengan jumlah 6 orang. Kadar trigliserida tertinggi kedua berada pada rentang usia 51-60 tahun dengan jumlah 4 orang, dan kadar trigliserida tertinggi ketiga berada pada rentang usia 41-50 tahun dengan jumlah 3 orang.

Berdasarkan jenis kelamin, terdapat laki-laki dengan trigliserida tinggi sebanyak 7 orang sedangkan perempuan dengan trgliserida tinggi sebanyak 5 orang.

Berdasarkan jenis pekerjaan, terdapat trigliserida tertinggi pada pegawai negeri sipil dan swasta masing-masing sebanyak 5 orang dan yang trigliserida tinggi paling sedikit terdapat pada orang yang tak bekerja.

\section{SARAN}

Saran yang dapat peneliti berikan adalah agar dilakukan pemberian penyuluhan kepada masyarakat dalam hal faktor penyebab peningkatan kadar lipid trigliserida di Kota Manado khususnya di lingkup kerja Puskesmas Bahu, Kecamatan Malalayang. Hal ini diharapkan dapat menurunkan angka kadar trigliserida yang tinggi pada masyarakat. Penelitian selanjutnya diharapkan membahas hubungan antara obesitas dengan peningkatan kadar lipid trigliserida.

\section{DAFTAR PUSTAKA}

1. Marks DB, Marks AD, Smith CM. Biokimia kedokteran dasar. Jakarta: Penerbit buku kedokteran ECG; 2000.

2. Pitoyo AJ, Kiswanto E, Rahmat PN, Fauziah S. Menjadi Produktif di Usia Produktif. Jakatra: Badan Kependudukan dan Keluarga Berencana Nasional; 2013.

3. Kasliwal RR, Kulshreshtha A, Agrawal S, Bansal M, dan Trehan N. Prevalence of cardiovascular risk fator in Indian patient undergoing coronary artery bypass surgery. Journal of the Association Phisicians India. JAPI 54; 2006.

4. Haddad FH, Omari AA, Shamailah QM, Malkawi OM, et al. Lipid profile in patients with coronary artery disease. Saudi Med J. 2002; 23(9): 10541058.

5. Amwila, A.Y, M.C. Linder, A. Parakkasi. 1992. Biokimia Nutrisi dan Metabolisme. Jakarta: Penerbit Universitas Indonesia. 
6. Goff DC, Bertoni AG, Kramer H, Bonds D, Blumenthal RS, Tsai MY, Psaty BM. Dyslipidemia Prevalence, Treatment, and Control in the MultiEthnic Study of Atherosclerosis (MESA): Gender, Ethnicity, and Coronary Artery Calcium.
Circulation-Journal of American heart association, 2006 Vol. 113:647-656. USA.

7. Kuchel P, Ralston GB. Schaum's Easy outline Biokimia. Jakarta: Penerbit Erlangga; 2006. 